\title{
Polymorphism of the GDF9 Gene in Russian Sheep Breeds
}

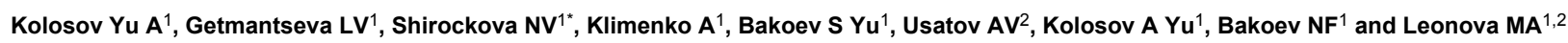

'Don State Agrarian University, Persianovskiy, Russia

${ }^{2}$ Southern Federal University, Rostov-on-Don, Russia'

*Corresponding author: Shirockova NV, Kolosov A.Yu., Don State Agrarian University, Persianovskiy, Russia, Tel: 89185610149; E-mail: ilonaluba@mail.ru

Rec date: Dec 22, 2014, Acc date: Jan 07, 2014, Pub date: Jan 09, 2014

Copyright: (c) 2015 Kolosov Yu A, et al. This is an open-access article distributed under the terms of the Creative Commons Attribution License, which permits unrestricted use, distribution, and reproduction in any medium, provided the original author and source are credited.

\begin{abstract}
Growth differentiation factor 9 (GDF9) plays a key role in the fertility of most mammalian species. Ovine GDF9 gene is localized in the 5 th chromosome. The gene's length is $2.5 \mathrm{~kb}$ consisting of two exons separated by one intron (1126 bp) and encodes a pro-peptide comprising 453 amino acids. The mature peptide includes 135 amino acids.

The purpose of this paper is to determine the GDF9 polymorphism in sheep of Salskaya and Romanov breeds in Rostov region of Russia. Polymorphism was identified by PCR- RFLP method at points G1 (G260A) and G4 (G721A). AG and GG genotypes were detected at points $G 1$ and $A A$ and $A G$ genotypes were detected at points $G 4$ in Salskaya sheep breed, frequency of $A$ was 0.05 and $G$ allele 0.95 (at point $G 1$ ) and frequency of $A$ was 0.95 and G allele 0.05 (at point G4). In Romanov breed $A G$ and $G G$ genotypes were detected at points $G 1$ and $A A$ and $A G$ genotypes were detected at points $G 4$, frequency of $A$ was 0.20 and $G$ allele 0.80 (at point $G 1$ ) and frequency of $A$ was 0.80 and $\mathrm{G}$ allele 0.20 (at point $\mathrm{G} 4$ ).
\end{abstract}

Keywords: GDF9; Gene; Polymorphism; PCR- RFLP; Sheep; Fertility

\section{Introduction}

Modern trends in sheep breeding include the use of new methods based on the application of DNA technologies, thus providing the industry being profitable and competitive $[1,2]$. Marker selection is an important trend in practical genetics (Marker Assisted Selection MAS), suggesting the use of DNA markers associated with productivity traits $[3,4]$. The DNA marker-based technologies are widely applied in national breeding programs in several countries with developed sheep breeding $[5,6]$.

In Rostov region there is a gradual increase of sheep livestock after its significant decline, so a more profound approach to restocking based on modern technologies is needed. The traditional assessment should be supplemented by a genetic control system.

Improvement of reproductive traits of sheep is one of the main objectives of breeding work. Direct selection by fertility is characterized by relatively low efficiency, which is connected, on the one hand, with low heritability sig ns, on the other hand, with a limited manifestation gender. In this regard, the studies aimed at finding DNA markers responsible for the development of these features and their identification are of current interest and demand. Today, the growth differentiation factor 9 (GDF9) is one of the most promising genes for sheep prolificacy $[7,8]$. Glycoprotein GDF-9, the protein product of the gene is structurally similar to beta (TGF-b), the growth transforming factor. Research on the role of GDF9 in folliculogenesis, revealed that it is the oocyte - specific growth factor and greatly contributes to the growth and differentiation of granulose cells, as well as to the formation of theca cells and fertility of most mammalian species $[9,10]$.
The ovine GDF9 gene was determined in the 5th chromosome $[11,12]$. The length of the gene is approximately $2.5 \mathrm{~kb}$ consisting of two exons separated by one intron (1126 bp) and coding a propeptide of 453 amino acids, with the mature peptide being composed of 135 amino acids [13].

Eight different mutations (G1-G8) have been identified in the gene GDF9 (Table 1) [12]. Three mutations of eight ones do not result in the modification of amino acid sequence (G2, G3 and G5). Five remaining nucleotide substitutions (G1, G4, G6, G7 and G8) lead to amino acid changes. In this context, the aim is to study the diversity of allelic variants of the GDF9 gene (by points GDF9/G1 and GDF9/G4) in sheep of Salskaya and Romanov breeds.

\begin{tabular}{|l|l|l|}
\hline $\begin{array}{l}\text { Variant of } \\
\text { GDF9 gene }\end{array}$ & Base change & Amino acid change \\
\hline G1 & G-A & Arg (R)-His (H) \\
\hline G2 & C-T & UnchangedVal (V) \\
\hline G3 & G-A & UnchangedLeu (L) \\
\hline G4 & G-A & Glu (E)-Lys (K) \\
\hline G5 & A-G & UnchangedGlu (E) \\
\hline G6 & G-A & Val (V)-Ile (I) \\
\hline G7 & G-A & Val (V)-Met (M) \\
\hline G8 & C-T & Ser (S)-Phe (F) \\
\hline
\end{tabular}

Table 1: Polymorphic sequence variations in GDF9 (Hanrahan et al., 2004). 
Citation: Kolosov Yu A, Getmantseva LV, Shirockova NV, Klimenko A, Bakoev S Yu, et al. (2015) Polymorphism of the GDF9 Gene in Russian Sheep Breeds. J Cytol Histol 6: 305. doi:10.4172/2157-7099.1000305

Page 2 of 4

\section{Materials and Methods}

The subjects of study were Salskaya $(n=100)$ and Romanov sheep breed $(n=60)$ of the Rostov region. Isolation of DNA from the samples was DIAtom DNA Prep 100 ("Genlab" LTD, Russia) of GDF9. The analysis of allelic variants of the GDF9 (by points G1 and G4) was carried out by PCR- RFLP as described by Hanrahan et al. [12]. The specific primers presented in Table 2. PCR conditions: initial denaturation -2 min at $94^{\circ} \mathrm{C}$; denaturation at $94^{\circ} \mathrm{C}-30$ sec., annealing at $63^{\circ} \mathrm{C}-40 \mathrm{sec}$., elongation at $72^{\circ} \mathrm{C}-30 \mathrm{sec}$. ( $\left.35 \mathrm{cycles}\right)$, final elongation at $72^{\circ} \mathrm{C}-4$ minutes.

\begin{tabular}{|l|l|l|}
\hline Points of GDF9 & Primers & Fragment length (bp) \\
\hline G1 & $\begin{array}{l}\text { 5'- GAAGACTGGTATGGGGAAATG -3' } \\
\text { 5'- CCAATCTGCTCCTACACACCT -3' }\end{array}$ & 462 \\
\hline G4 & $\begin{array}{l}\text { 5'- GGAATATTCACATGTCTGTAAATTTTACATGTTGG -3' } \\
\text { 5'-GAGGGAATGCCACCTGTGAAAAGCC -3' }\end{array}$ & 161 \\
\hline
\end{tabular}

Table 2: The oligonucleotide primers.

PCR- RFLP analysis of the GDF9-G1 gene fragment with the length of $462 \mathrm{bp}$ was performed using restriction enzyme BstHHl (GCG $\uparrow \mathrm{C}$ to $C \downarrow G C G)$. Restriction fragments were separated in the $2 \%$ agarose gel.

PCR- RFLP analysis of the GDF9-G4 gene fragment GDF9-G4 with the length of $161 \mathrm{bp}$ was performed using restriction enzyme Bpu14 I (TT^CGAA to AAGC $\downarrow T T$ ). Restriction fragments were separated in the $3 \%$ agarose gel. POPGENE software was used to estimate the allele and genotypes frequencies.

\section{Results and Discussion}

Salskaya breed (Figure 1a) was developed the Rostov region for almost 20 years (1930-1950). Breeding work of developing a new breed of fine-wool sheep targeted on breeding sheep with strong constitution without exterior defects and shortcomings, well adapted to grazing conditions and capable of walking long distances during migration and of full use of sparse grass in Sal'sk prairie [14].

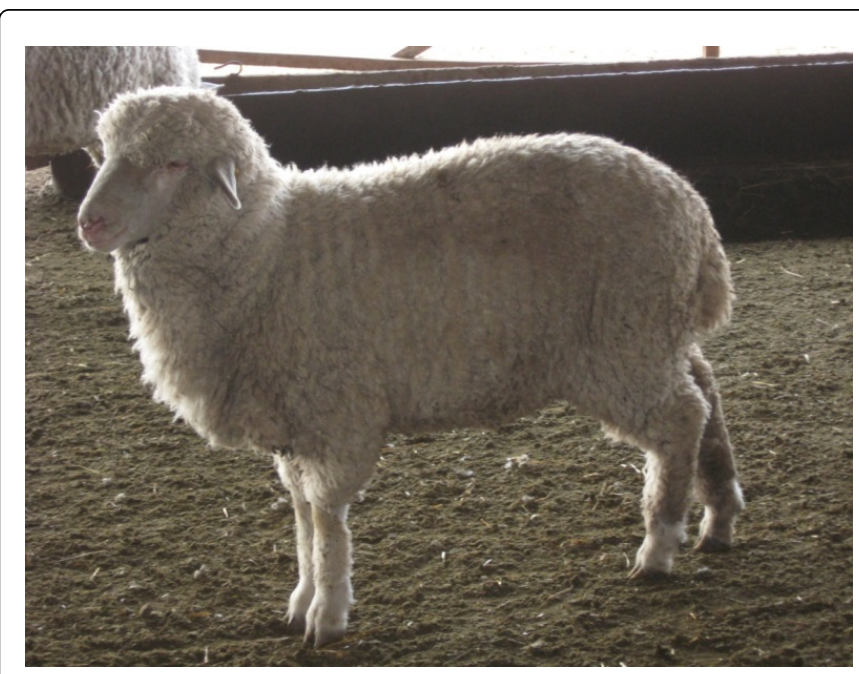

Figure 1a: Salskaya sheep breed.

Romanov breed is an ancient breed and at the same time one of the most promising ones in Russia. The Romanov breed sheep are rather big animals with weight of $80-100 \mathrm{~kg}$ (rams) and 60-70 kg (ewes) (Figure 1b). A sheep produces an average of more than two lambs with frequent triplets, and even quadruplets and five lambs.

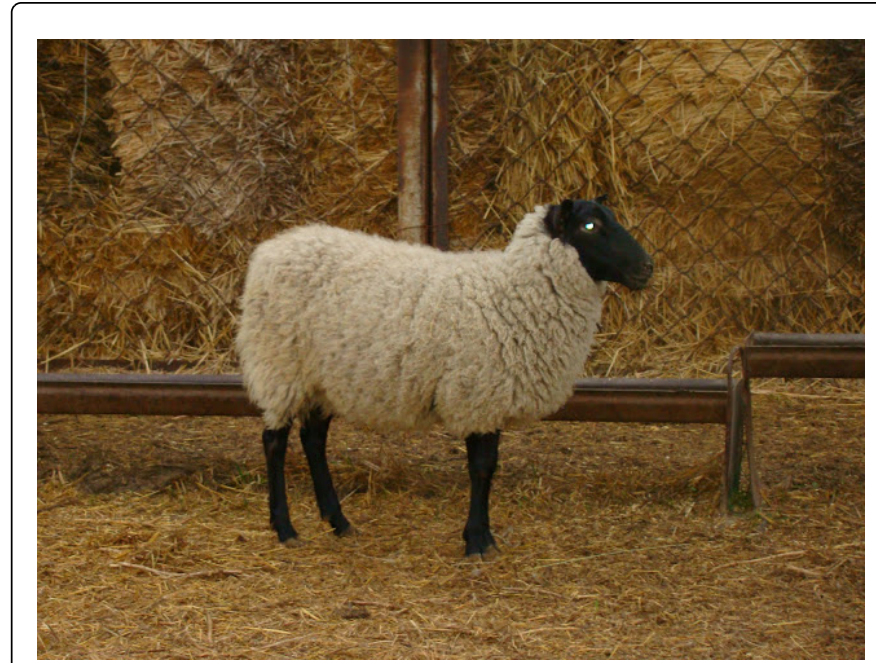

Figure 1b: The Romanov sheep.

The results of studies of Salskaya and Romanov sheep indicated polymorphism of the GDF9 gene by points G1 (Figure 2) and G4 (Figure 3). The obtained results of allele and genotype frequencies of the GDF9 gene showed a very low level of polymorphism by points G1 and G4 in the population of Salskaya sheep breeds under study (Table $3)$. The Salskaya sheep displayed high frequency of $G$ allele (0.95) and GG genotype (90\%) at point G1 and A allele (0.95) and AA genotype $(90 \%)$ at point G4 of GDF9 gene. Homozygous AA genotype (G1) and GG (G4) in the study population were not observed.

In the population of Romanov sheep under study the results of allele and genotype frequencies of the GDF9 gene showed a higher level of polymorphism by the points G1 and G4, compared with a population of Salskaya sheep (Table 3). The Romanov sheep also had higher frequencies of $\mathrm{G}$ allele (0.80) and GG genotype (60.9\%) by point G1 and A allele (0.80) and AA genotype (60.9\%) by point G4 of the GDF9 gene. It should be noted that all individual animals being heterozygous by the point $\mathrm{G} 1$, were heterozygous by the point $\mathrm{G} 4$, as well.

PCR-RFLP is a reliable and simple method used to study polymorphism gene GDF9 in various breeds of sheep by some research groups. The data of our study in Salskaya and Romanov 
Citation: Kolosov Yu A, Getmantseva LV, Shirockova NV, Klimenko A, Bakoev S Yu, et al. (2015) Polymorphism of the GDF9 Gene in Russian

breeds in Rostov region of Russia showed a low frequency of allele A and the absence of genotype AA at point G1

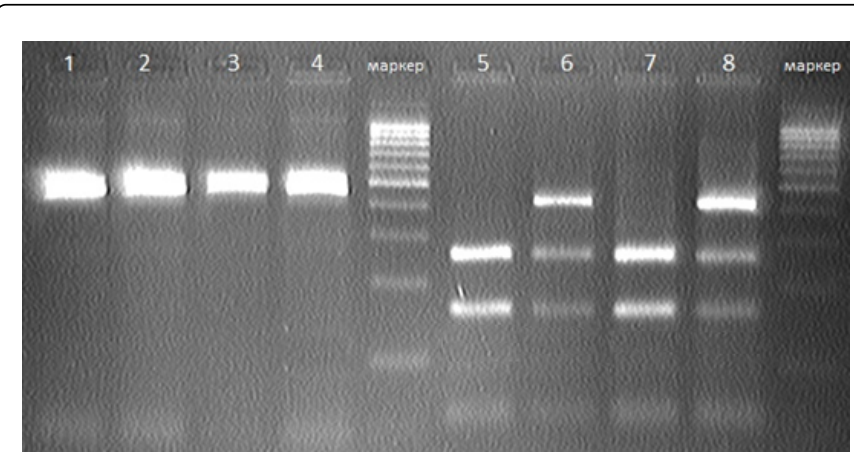

Figure 2: The result of PCR- RFLP of GDF9/G1 in the 2\% agarose gel Denotations: 1-4 - PCR product of the gene GDF9/G1 (462 bp.); 5, 7 - GG genotype; 6, 8 - AG genotype; маркер - DNA Marker100 bp.

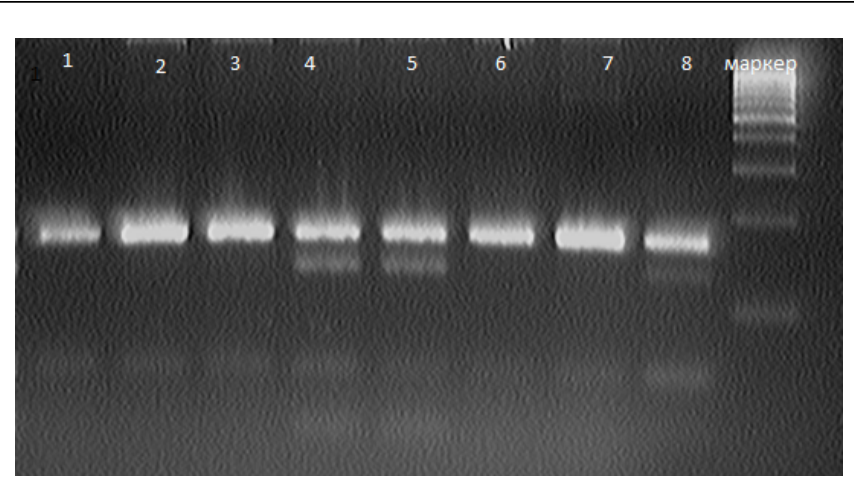

Figure 3: The result of PCR- RFLP of GDF9/G4 in the 3\% agarose gel Denotations: 1-3 - The PCR product of the gene GDF9/G4 (161 bp); 4, 5, 8- AG genotype; 6, 7 - AA genotype; маркер - DNA Marker100 bp.

\begin{tabular}{|c|c|c|c|c|c|}
\hline \multirow{2}{*}{$\begin{array}{l}\text { Variant of } \\
\text { GDF9 gene }\end{array}$} & \multicolumn{2}{|c|}{ Alleles } & \multicolumn{3}{|c|}{ Genotypes, \% } \\
\hline & A & $G$ & AA & $A G$ & GG \\
\hline \multicolumn{6}{|c|}{ Salskaya sheep } \\
\hline G1 & 0.05 & 0.95 & - & 10.0 & 90.0 \\
\hline G4 & 0.95 & 0.05 & 90.0 & 10.0 & - \\
\hline \multicolumn{6}{|c|}{ Romanov sheep } \\
\hline G1 & 0.20 & 0.80 & - & 39.1 & 60.9 \\
\hline G4 & 0.80 & 0.20 & 60.9 & 39.1 & - \\
\hline
\end{tabular}

Table 3: Frequencies of alleles and genotypes of the GDF9 of Salskaya and Romanov sheep.

These results are in agreement with reports in Sheep Hisari Tajikistan race [15]. GG, AG and AA genotypes were frequency 93.64, 6.36 and $0 \%$ and $\mathrm{G}$ and $\mathrm{A}$ alleles frequency were 0.97 and 0.03 , respectively. Similar results were obtained in Kordi and Arabic sheep [13], where A allele frequencies were 0.09 and 0.08 , respectively.

The analysis of polymorphism for GDF9 (G1) in Baluchi sheep indicated all three possible genotypes, however allele $\mathrm{G}$ had the highest frequency (0.82), whereas allele A had the lowest frequency (0.18) [16]. The genotype frequencies of GG, AG and AA were 0.72.0, 20.0 and $8.0 \%$, respectively. Resulted polymorphism in GDF9 in Sangsari sheep showed same results, genotype frequencies for GG, AG and AA were $70.72,36.88$ and $1.40 \%$ and allele frequencies for $\mathrm{G}$ and $\mathrm{A}$ were 0.80 and 0.19 , respectively [17].

\section{Conclusion}

The diversity of polymorphism of the GDF9 gene (by points GDF9/G1 and GDF9/G4) of Salskaya and Romanov sheep has been studied. The results obtained showed a low level of polymorphism by the points under study, but the presence of heterozygous variants in the investigated population gives grounds to assume that further research in this area will contribute to the identification of informative genes related to productive traits of sheep.

\section{Acknowledgement}

This research was supported by the Russian Ministry of Education and Science, project no. 40.91.2014/K.

\section{References}

1. Chu MX, Liu ZH, Jiao CL, He YQ, Fang L, et al. (2007) Mutations in BMPR-IB and BMP-15 genes are associated with litter size in Small Tailed Han sheep (Ovis aries). J Anim Sci 85: 598-603.

2. Karagodina N, Kolosov Y, Usatov A, Bakoev S, Kolosov A, et al. (2014).Influence of Various Bio-Stimulants on the Biochemical and Hematological Parameters in Porcine Blood Plasma. World Applied Sciences 30: 723-726.

3. Yang WC, Li SJ, Tang KQ, Hua GH, Zhang CY, et al. (2010) Polymorphisms in the 5 ' upstream region of the FSH receptor gene, and their association with superovulation traits in Chinese Holstein cows. Anim Reprod Sci 119: 172-177.

4. Klimenko A, Usatov A, Getmantseva L, Kolosov Yu, Tretyakova O, et al. (2014) Effect of melanocortin-4 receptor gene on growth and meat traits in pigs raised in Russia. American Journal of Agricultural and Biological Sciences 9: 232-237.

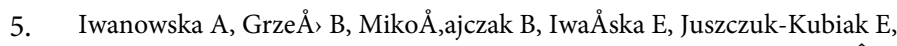
et al. (2011) Impact of polymorphism of the regulatory subunit of the $\hat{I}^{1 / 4}$ - 
Citation: Kolosov Yu A, Getmantseva LV, Shirockova NV, Klimenko A, Bakoev S Yu, et al. (2015) Polymorphism of the GDF9 Gene in Russian Sheep Breeds. J Cytol Histol 6: 305. doi:10.4172/2157-7099.1000305

Page 4 of 4

calpain (CAPN1S) on the proteolysis process and meat tenderness of young cattle. Mol Biol Rep 38: 1295-1300.

6. Chu MX, Guo XH, Feng CJ, Li Y, Huang DW, et al. (2012) Polymorphism of 5 ' regulatory region of ovine FSHR gene and its association with litter size in Small Tail Han sheep. Mol Biol Rep 39: 3721-3725.

7. Bodensteiner KJ, Clay CM, Moeller CL, Sawyer HR (1999) Molecular cloning of the ovine Growth/Differentiation factor-9 gene and expression of growth/differentiation factor-9 in ovine and bovine ovaries. Biol Reprod 60: 381-386.

8. Chung H, Davis M (2014) Effects of genetic variants and mapping assignments of the ovine calpain regulatory subunit gene on chromosome 14. Genes \& Genomics 36: 465-473.

9. Laitinen M, Vuojolainen K, Jaatinen R, Ketola I, Aaltonen J, et al. (1998) A novel growth differentiation factor-9 (GDF-9) related factor is coexpressed with GDF-9 in mouse oocytes during folliculogenesis. Mech Dev 78: 135-140.

10. Davis GH (2005) Major genes affecting ovulation rate in sheep. Genet Sel Evol 37:11-23.

11. Sadighi M, Bodensteiner KJ, Beattie AE, Galloway SM (2002) Genetic mapping of ovine growth differentiation factor 9 (GDF9) to sheep chromosome 5. Anim Genet 33: 244-245.
12. Hanrahan JP, Gregan SM, Mulsant P, Mullen M, Davis GH, et al. (2004) Mutations in the genes for oocyte-derived growth factors GDF9 and BMP15 are associated with both increased ovulation rate and sterility in Cambridge and Belclare sheep (Ovis aries). Biol Reprod 70: 900-909.

13. Ghaderi A, BeigiNasiri M, Mirzadeh KH, Fayazi J, Sadr AS (2010) Identification of the GDF9 mutation in two sheep breeds by using polymerase chain reaction- restriction fragment length polymorphism (PCR-RFLP) technique. African Journal of Biotechnology 9: 8020-8022.

14. Kolosov Yu, Getmantseva L, Shirockova N (2013) Sheep Breeding Resources in Rostov Region. World Applied Sciences Journal 23:1322-1324.

15. Bahrami Y, Bahrami S, Mohammadi H, Chekani-Azar V, Mousavizadeh S (2014) The Polymorphism of GDF-9 Gene in Hisari Shep. Biological Forum - An International Journal 6: 46-52.

16. Moradband F, Rahimi G, Gholizadeh M (2011) Association of Polymorphisms in Fecundity Genes of GDF9, BMP15 and BMP15-1B with Litter Size in Iranian Baluchi Sheep Asian-Aust. J Anim Sci 24: 1179-1183.

17. Kasiriyan MM, Hafezian SH, Hassani N (2011) Genetic polymorphism BMP15 and GDF9 genes in Sangsari sheep of Iran. International Journal of Genetics and Molecular Biology 3: 31-34. 